\title{
Inhaled tyrosine kinase inhibitors for pulmonary hypertension: a possible future treatment
}

\author{
This article was published in the following Dove Press journal: \\ Drug Design, Development and Therapy \\ 7 October 2014 \\ Number of times this article has been viewed
}

\section{Georgia Pitsiou' \\ Paul Zarogoulidis' \\ Dimitris Petridis ${ }^{2}$ \\ loannis Kioumis' \\ Sofia Lampaki' \\ John Organtzis \\ Konstantinos Porpodis' \\ Antonis Papaiwannou' \\ Theodora Tsiouda ${ }^{3}$ \\ Wolfgang Hohenforst- \\ Schmidt ${ }^{4}$ \\ Stylianos Kakolyris ${ }^{5}$ \\ Konstantinos Syrigos ${ }^{6}$ \\ Haidong Huang ${ }^{7}$ \\ Qiang $\mathrm{Li}^{7}$ \\ J Francis Turner ${ }^{8}$ \\ Konstantinos Zarogoulidis'}

'Pulmonary Department, G Papanikolaou General Hospital, Aristotle University

of Thessaloniki, ${ }^{2}$ Department of Food

Technology, School of Food Technology

and Nutrition, Alexander Technological

Educational Institute, ${ }^{3}$ Internal Medicine

Department, Thegenio Anticancer

Hospital, Thessaloniki, Greece; ${ }^{4}$ Il Medical

Department, Coburg Regional Hospital,

Coburg, Germany; ${ }^{5}$ Oncology Department,

Sotiria Hospital of Chest Diseases,

University of Athens, Athens, ${ }^{6}$ Oncology

Department, University General Hospital

of Alexandroupolis, Democritus University

of Thrace, Alexandroupolis, Greece;

${ }^{7}$ Department of Respiratory Diseases,

Changhai Hospital/First Affiliated Hospital

of the Second Military Medical University,

Shanghai, People's Republic of China;

${ }^{8}$ Division of Interventional Pulmonology and Medical Oncology, Cancer Treatment

Centers of America, Western Regional

Medical Center, Goodyear, AZ, USA

Correspondence: Paul Zarogoulidis Pulmonary Department, G Papanikolaou General Hospital, Aristotle University of Thessaloniki, Thessaloniki, Greece

Tel +306977271974

Fax +302310992432

Email pzarog@hotmail.com
Abstract: Pulmonary hypertension is a disease with severe consequences for the human body. There are several diseases and situations that induce pulmonary hypertension and are usually underdiagnosed. Treatments include conventional medical therapies and oral, inhaled, intravenous, and subcutaneous options. Depending on its severity, heart or lung transplant may also be an option. A possible novel treatment could be tyrosine kinase inhibitors. We conducted experiments with three jet nebulizers and three ultrasound nebulizers with erlotinib, gefitinib, and imatinib. Different residual cup designs and residual cup loadings were used in order to identify the best combination to produce droplets of less than $5 \mu \mathrm{m}$ in mass median aerodynamic diameter. We found that gefitinib could not be transformed into a powder, so conversion to an aerosol form was not possible. Our experiments indicated that imatinib is superior to erlotinib with regard to small droplet size formation using both inhaled technologies $(1.37 \mu \mathrm{m}<2.23 \mu \mathrm{m}$ and $1.92 \mu \mathrm{m}<3.11 \mu \mathrm{m}$, jet and ultrasound, respectively) and, at jet devices $(1.37 \mu \mathrm{m}<1.92 \mu \mathrm{m})$. Cup designs $\mathrm{C}$ and $\mathrm{G}$ contribute best to small droplet creation uniquely supporting and equally well the activity of both drugs. The disadvantage of the large droplets formed for erlotinib was offset when combined with residual cup $\mathrm{C}(1.37 \mu \mathrm{m}$ instead of $2.23 \mu \mathrm{m})$. At a $2 \mathrm{~mL}$ dose, the facemask and cone mouthpieces performed best and evenly; the facemask and low dose were the best choice $(2.08 \mu \mathrm{m}$ and $2.12 \mu \mathrm{m}$, respectively). Erlotinib and imatinib can be administered as an aerosols, and further in vivo experimentation is necessary to investigate the positive effects of these drugs in the treatment of pulmonary hypertension.

Keywords: erlotinib, gefitinib, imatinib, jet nebulizers, ultrasound nebulizers

\section{Introduction}

Pulmonary hypertension (PH) refers to increased blood pressure in the large vessels of the pulmonary artery, pulmonary capillaries, and/or pulmonary vein. It affects the entire lung vasculature, leading to orthopnea, fainting, dizziness, fatigue, non-productive cough, peripheral edema, angina pectoris, and leg swelling. PH is considered to be a serious disease, and in the final stages is often associated with decreased exercise tolerance and heart failure. Symptoms usually develop gradually, and patients may delay seeking medical attention for years, only seeking assistance from a physician when symptoms appear, such as coughing up blood and/or syncope. It is known that venous hypertension typically presents with shortness of breath while lying flat, whereas pulmonary arterial hypertension (PAH) usually does not. $\mathrm{PH}$ is known to have five variants, so several tests have to be performed to distinguish PAH from venous, thromboembolic, miscellaneous, or hypoxic PH. Moreover, physicians must bear in mind pertinent statutes that induce $\mathrm{PH}$ and exclude other possible diagnoses. Common investigations include pulmonary function tests, screening for autoimmune diseases, blood tests to exclude human immunodeficiency virus, electrocardiography, liver function tests, arterial blood gas measurements, ventilation-perfusion studies, 
a ventilation-perfusion scan to exclude chronic thromboembolic $\mathrm{PH}$, and chest radiography. Lung biopsy is not indicated unless underlying interstitial lung disease is suspected.

Clinical improvement in such patients is measured by the 6-minute walk test. It has been observed that improved performance on this test correlates with increased survival benefit. The blood brain natriuretic peptide level is nowadays considered a marker for disease stability or progression in patients with $\mathrm{PH}$. PAH pressure can usually be estimated in everyday clinical practice with echocardiography; however, the gold standard is pressure measurement with a SwanGanz catheter through the right side of the heart. Pulmonary artery occlusion pressure and pulmonary vascular resistance cannot be measured directly with echocardiography. Rightsided cardiac catheterization is required for diagnosis of PAH. In order to measure cardiac output accurately, we use a Swan-Ganz catheter; this method being by far superior for measuring PAH. ${ }^{1}$ Normal pulmonary arterial pressure has been observed to be $8-20 \mathrm{mmHg}(1,066-2,666 \mathrm{~Pa})$ at rest. PH is observed when mean pulmonary artery pressure exceeds $25 \mathrm{mmHg}$ at rest.

The treatment depends on whether the $\mathrm{PH}$ is arterial, hypoxic, venous, thromboembolic, or miscellaneous. In the case of congestive heart failure, diuretics or angiotensinconverting enzyme inhibitors can be given to improve left ventricular function, repair/replace the mitral valve or aortic valve, and beta-blockers. Patients with known left heart failure or hypoxemic lung disease (group II or III $\mathrm{PH}$ ) should not be treated with vasoactive agents such as phosphodiesterase inhibitors, endothelin antagonists, or prostanoids, because these agents are only approved for PAH. ${ }^{2}$ To make the distinction, physicians perform a chest computed tomography scan, cardiac catheterization of the right heart, echocardiography, and a six-minute walk test. In PAH, diuretics, digoxin, oxygen therapy, and oral anticoagulants are usually considered to be appropriate therapy. It has been observed that high-dose calcium channel blockers are useful in only $5 \%$ of patients with idiopathic PAH who are vasoreactive on Swan-Ganz catheterization. ${ }^{3}$ Only half of these patients respond to calcium channel blockers in the long-term. ${ }^{4}$ Several new agents have been introduced for primary and secondary PAH. However, there are few trials supporting the use of these agents, and the only measure consistently used to compare their efficacy is the 6-minute walk test. Most have no data on mortality benefit or time to progression. ${ }^{5}$

Tyrosine kinase inhibitors (TKIs) are presently being evaluated as to whether they could be used as a treatment for PH. ${ }^{6}$ Imatinib has been investigated in several studies to determine if it is effective against $\mathrm{PH} \cdot{ }^{7-11}$ Moreover, other agents, such erlotinib and gefitinib, which have been used effectively in the treatment of lung cancer, could be also considered for PH. ${ }^{6,12,13}$ However, orally administered TKIs have serious side effects, which has generated a quest for alternative routes of administration, such as inhalation. ${ }^{14}$ In this work, we investigated whether erlotinib, gefitinib, and imatinib could be modified for aerosol administration using jet and ultrasound nebulizers. We also sought to determine the best combination of residual cup design, residual cup loading, and nebulizer, for producing droplets less than $5 \mu \mathrm{m}$ in size.

\section{Materials and methods Drugs}

Erlotinib (150 mg tablets; Tarceva ${ }^{\circledR}$; Roche, Basel, Switzerland), gefitinib (250 mg tablets; Iressa ${ }^{\circledR}$; AstraZeneca, London, UK), and imatinib (400 mg tablets; Glivec ${ }^{\circledR}$; Novartis, Basel, Switzerland) were sourced from our oncology department.

\section{Aerosol production systems}

\section{Jet nebulizers and residual cups}

Three jet nebulizers, ie, Maxineb ${ }^{\circledR}$ (Flexicare Medical Ltd., Mountain Ash, UK; 6 L per minute and 35 psi); Sunmist ${ }^{\circledR}$ (Nursing Hygiene, Southwater, UK; 5-7 L per minute and $35 \mathrm{psi}$ ); and Invacare $^{\circledR}$ (Invacare Corporation, Elyria, $\mathrm{OH}$, USA; 4-8 L per minute and $36 \mathrm{psi}$ ) were chosen for the experiment (Figure 1). We opted to use seven residual cups, of which four had a capacity of no more than $6 \mathrm{~mL}$ and two had a capacity of no more than $10 \mathrm{~mL}$. The large cups were designated using the letters $\mathrm{A}, \mathrm{D}$, and $\mathrm{E}$, and the small residual cups were designated C, F, B, and G (Figures 2 and 3). Large residual cups with a capacity of $2-8 \mathrm{~mL}$ were used. The residual cup loadings were $2,4,6$, and $8 \mathrm{~mL}$ ( $8 \mathrm{~mL}$ only for the large cups).

\section{Ultrasound nebulizers}

Three ultrasound nebulizers were selected. The first was the NE-U07 (Omron, Tokyo, Japan), which is compact and weighs less than $350 \mathrm{~g}$, includes a $10 \mathrm{~mL}$ medication cup, and generates uniform micrometer-sized vapor particles. The second was a portable Gima device (Gima SpA, Gessate, Italy). The third was a portable EASYneb ${ }^{\circledR}$ II (Flaem Nuova, Martino, Italy). The loadings were $2 \mathrm{~mL}$ and $4 \mathrm{~mL}$, since this is the amount held by the residual cup for each of the three ultrasound nebulizers. 


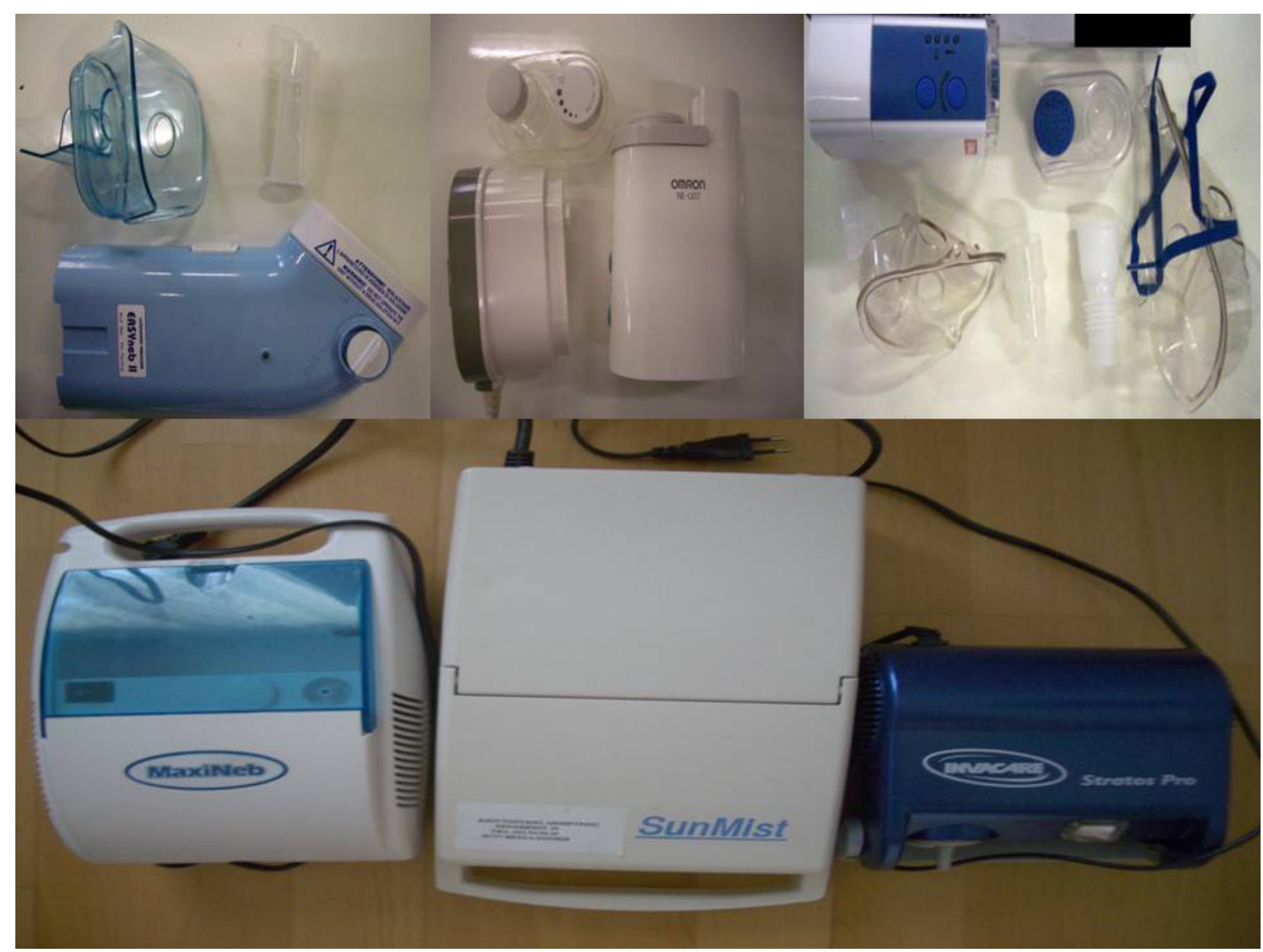

Figure I Ultrasound nebulizers (upper row) and jet nebulizers (lower row).

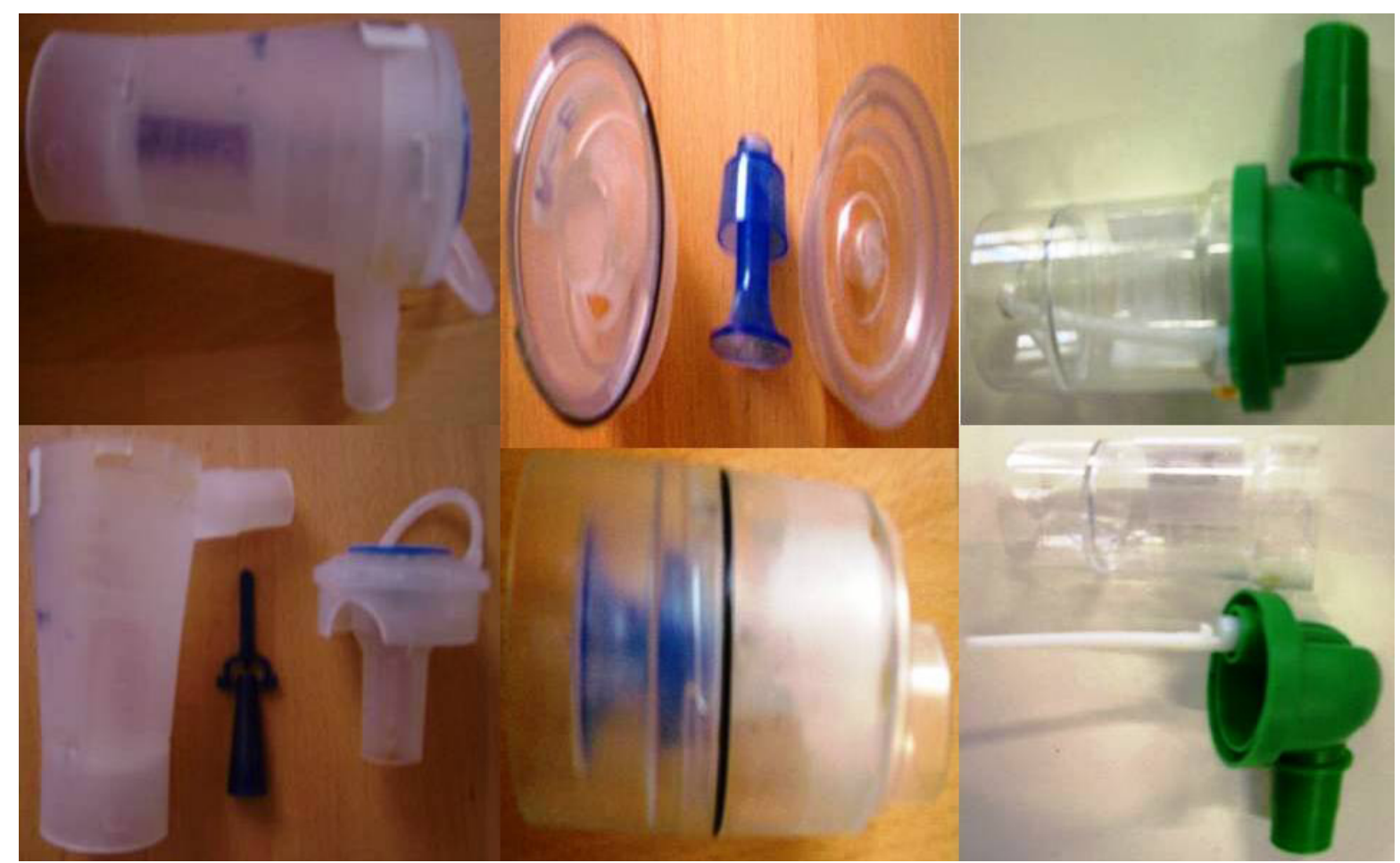

Figure 2 Large residual cups. 


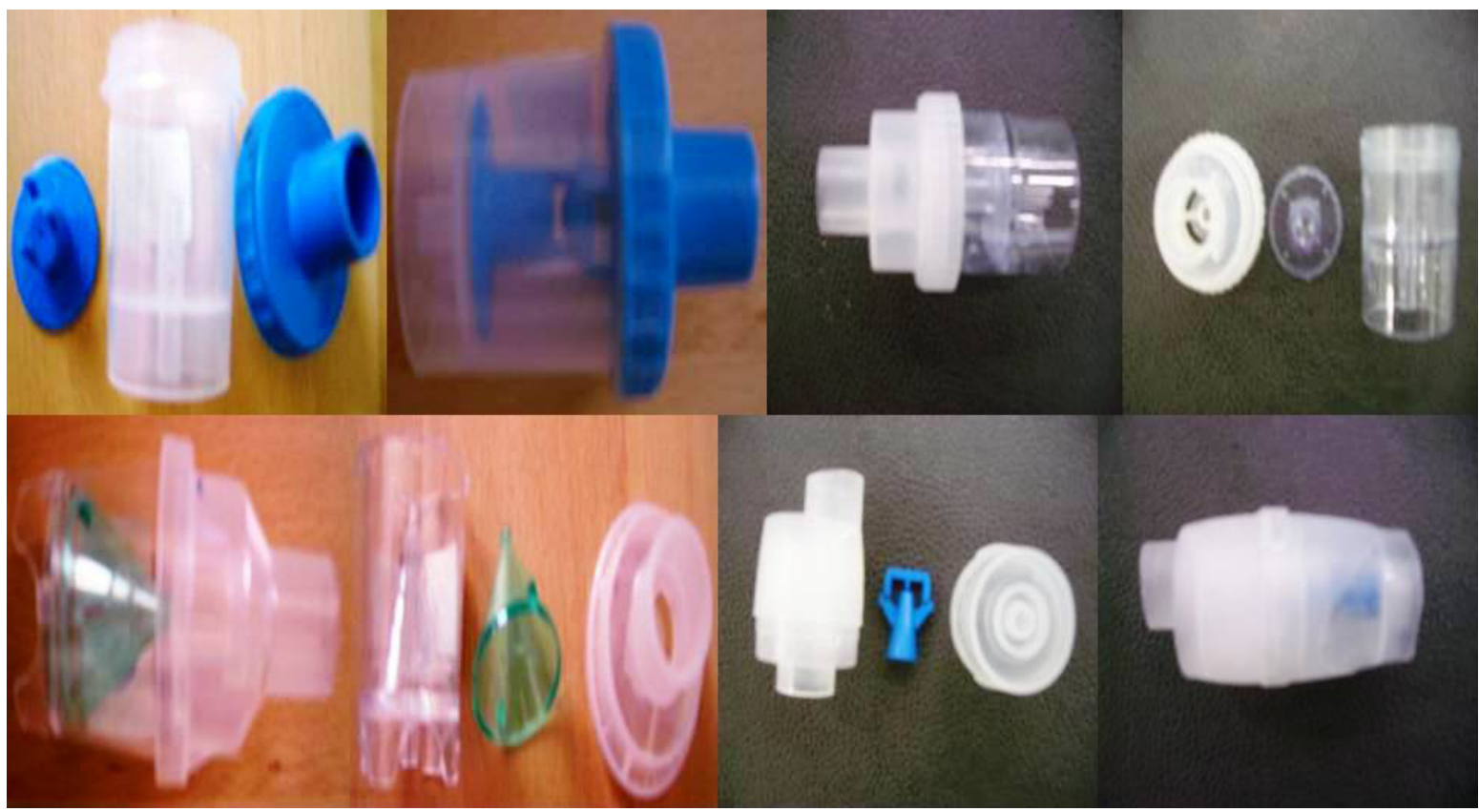

Figure 3 Small residual cups.

\section{Droplet measurement}

The size distribution of the droplets and their mean diameter $\left(d_{32}\right)$ were calculated using a Mastersizer 2000 (Malvern Instruments Ltd., Malvern, UK) equipped with a Scirocco module (Malvern). A refractive index of 1.33 was used for the sprayed droplets. Several experiments were performed repeatedly until optimal measurements were obtained, as in our previously reported experiments ${ }^{15-19}$ (Figure 4).

\section{Milling}

The erlotinib and imatinib tablets were milled in a planetary ball mill (Pulverisette-5; Frisch GmbH, München, Germany) equipped with agate bowls $(500 \mathrm{~mL})$ and eight balls $(20 \mathrm{~mm}, 20 \mathrm{~g})$ with a rotational speed of approximately $200 \mathrm{rpm}$, resulting in an acceleration of about $7.5 \mathrm{~g}$. We initiated our milling at 60 minutes for erlotinib and at 80 minutes for imatinib to obtain a mass median aerodynamic diameter $(M M A D) \leq 5 \mu \mathrm{m}$ (measured with the Mastersizer 2000). After milling, we collected powdered drug of the same weight and diluted it with $2 \mathrm{~mL}$ of $0.9 \% \mathrm{NaCl}$ in an effort to simulate a future method/compound of administration as an aerosol. We attempted to mill gefitinib for 320 minutes; however, it was impossible to convert the tablet to a powder (Figure 5).

\section{Statistical analysis}

Jet technology

Four factors were chosen as having a potential effect on droplet size: two drugs (erlotinib, imatinib), three nebulizers
(Invacare, Sunmist, Maxineb), seven residual cups (A-G), and three loading levels $(2,4$, and $6 \mathrm{~mL})$. Thus, a four-factor analysis of variance in combination with their interactions was conducted at the 0.05 probability reference level. Pairwise statistically significant differences between means were examined using the $95 \%$ confidence intervals of means. Two non-overlapping intervals indicate significant differences between the two means. A similar analysis of variance test was used for cups $\mathrm{A}, \mathrm{D}$, and $\mathrm{E}$ that could hold an $8 \mathrm{~mL}$ dose using the same drugs and nebulizers.

\section{Ultrasound technology}

The same drugs as above and three new nebulizers (EASYneb, Gima, Omron) manipulated at two dose levels (2 and $4 \mathrm{~mL}$ ) were tested for their potential impact on particle size.

\section{Results}

\section{Jet technology}

The drugs, cup designs, and their interaction effect were the most influential factors affecting MMAD (Table 1, $P<0.001)$. Imatinib dramatically decreased the mean droplet size down to $1.37 \mu \mathrm{m}$ as compared with the effect of erlotinib $(2.23 \mu \mathrm{m})$. Residual cups $\mathrm{C}$ and $\mathrm{G}$ lowered the particle size to a similar extent ( $1.32 \mu \mathrm{m}$ and $1.37 \mu \mathrm{m}$, respectively, Figure 6$)$, whereas the other cups had similar effects but produced droplets of a larger mean size. The strong diminishing effect of cups $\mathrm{C}$ and $\mathrm{G}$ expands also interactively and uniquely on the two drugs causing both imatinib and erlotinib to perform 


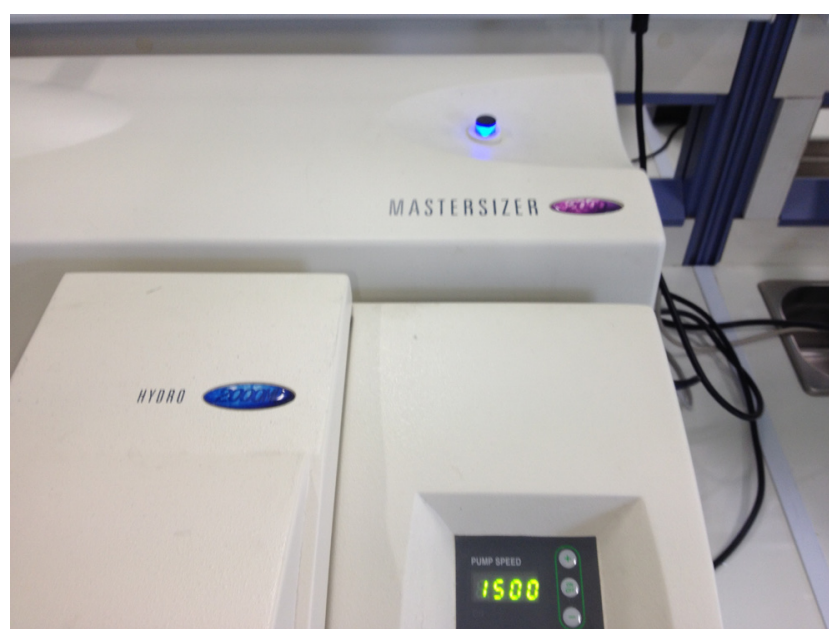

Figure 4 Mastersizer 2000.

evenly when these cups are applied (Figure 7), due to the wide overlap between their confidence intervals. The highest loading level $(6 \mathrm{~mL})$ appeared to be slightly less effective than the lower doses (Figure 8), but the effect was weakly statistically significant $(P=0.048)$. A loose interactive effect between cup design and the drugs was also established $(P=0.039)$, whereby erlotinib produced a larger mean droplet size $(2.57 \mu \mathrm{m})$ when combined with the Maxineb device (Figure 9). Another weak effect of a second order interaction (Table $1, P=0.038$ ) was considered negligible and not examined. The experiment focused on the highest loading level $(8 \mathrm{~mL})$ had no significant effect on the factors considered and was not investigated further.

\section{Ultrasound technology}

Drug activity, loading level, and mouthpiece operation all exerted a rather weak effect on particle size (Table 2, $P$-values $0.020,0.036$, and 0.043 , respectively). Imatinib

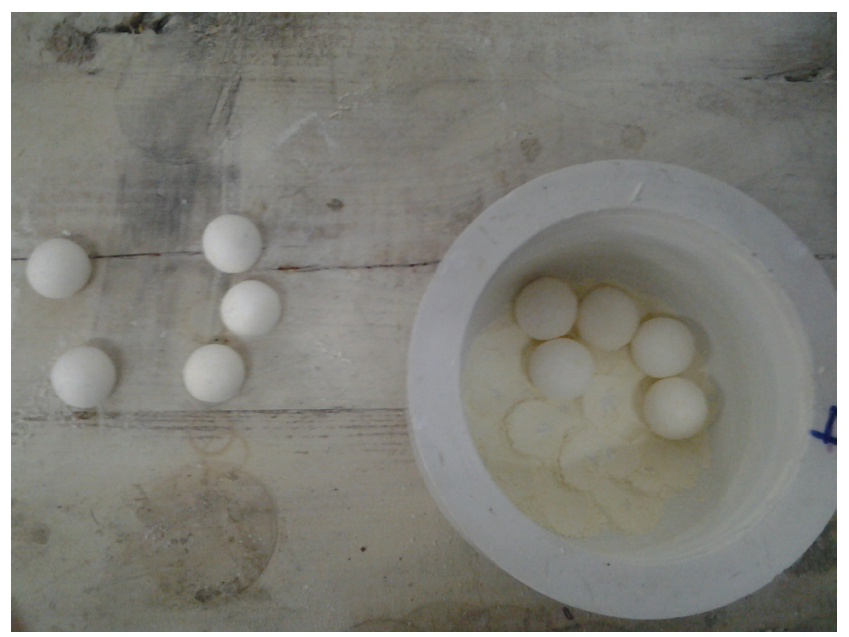

Figure 5 Porcelain milling ball. again performed better than erlotinib, forming smaller droplets $(1.92 \mu \mathrm{m}<3.11 \mu \mathrm{m}$, Table 3$)$. The facemask adaptation decreased the droplet size more than the cone $(2.12 \mu \mathrm{m}<2.91 \mu \mathrm{m})$, and so did the $2 \mathrm{~mL}$ dose when compared to the $4 \mathrm{~mL}$ dose $(2.08 \mu \mathrm{m}<2.95 \mu \mathrm{m})$. However, the performance of the cone device at the low dose was similar to that of the facemask with regard to droplet size $(2.10 \mu \mathrm{m}$ and $2.05 \mu \mathrm{m}$, respectively) as indicated by their interaction effect in Figure 10 (see also Table 2, $P=0.038$ ).

Imatinib outclassed the performance of erlotinib in terms of small droplet size formation using both inhaled technologies $(1.37 \mu \mathrm{m}<2.3 \mu \mathrm{m}$ and $1.92 \mu \mathrm{m}<3.11 \mu \mathrm{m}$ for jet and ultrasound, respectively) and when is considered alone, even better at jet devices $(1.37 \mu \mathrm{m}<1.92 \mu \mathrm{m})$. Cup designs $C$ and $\mathrm{G}$ contributed best to the creation of small droplets, supporting uniquely and equally well the activity of both drugs. The disadvantage of the large droplets formed by erlotinib was canceled out when the drug was combined with the residual cup C $(1.37 \mu \mathrm{m}$ instead of $2.23 \mu \mathrm{m}$, Figure 7). At the $2 \mathrm{~mL}$ dose, facemask and cone mouthpieces performed best and evenly, otherwise facemask and low dose give the best choice (2.08 $\mu \mathrm{m}$ and $2.12 \mu \mathrm{m}$, respectively).

\section{Discussion}

TKIs have been used for a number of years as targeted therapies for non-small cell lung cancer. ${ }^{20}$ Until now, neither erlotinib nor gefitinib has presented superiority between them. Both agents have been found to be effective as first-line treatment for epidermal growth factor-positive mutation tumors. Imatinib, on the other hand, is a TKI used in the treatment of multiple cancers, most notably Philadelphia chromosome-positive $\left(\mathrm{Ph}^{+}\right)$chronic myelogenous leukemia. ${ }^{21,22}$ Current data indicate that TKIs are potent acute pulmonary vasodilators, which prompted this work. ${ }^{23}$ The respiratory system has defense mechanisms, including mucus, beating cilia, and macrophages that block efficient aerosol deposition..$^{24}$ Moreover, aerosols targeted to the lung have to be designed so that the maximum MMAD is no larger than $5 \mu \mathrm{m}$. The reason is that due to the increased humidity of the respiratory system $>90 \%$, the aerosol droplets increase at least by $50 \%{ }^{24}$ Aerosol drug therapy targeted to the lung has been observed in many diseases to have the advantage of being more effective at lower doses and therefore to have fewer adverse effects. Two examples are inhaled insulin and inhaled chemotherapy, which have produced significant results when compared with intravenous or subcutaneous administration. ${ }^{25-30}$ In recent years, inhaled antibiotics have been investigated extensively, and there 
Table I Analysis of variance for effects of four fixed factors and their interactions on mass median aerodynamic diameter

\begin{tabular}{|c|c|c|c|c|c|}
\hline Effect & SS & $d f$ & MS & $\boldsymbol{F}$ & $P$-value \\
\hline Drug & 23.50 & I & 23.50 & 69.19 & 0.000 \\
\hline Nebulizer & 1.19 & 2 & 0.60 & 1.75 & 0.194 \\
\hline Residual cup & 13.01 & 6 & 2.17 & 6.39 & 0.000 \\
\hline Loading & 2.35 & 2 & 1.17 & 3.46 & 0.048 \\
\hline Drug*nebulizer & 2.52 & 2 & 1.26 & $3.7 I$ & 0.039 \\
\hline Drug*residual cup & 14.12 & 6 & 2.35 & 6.93 & 0.000 \\
\hline Nebulizer*residual cup & 7.00 & 12 & 0.58 & 1.72 & 0.126 \\
\hline Drug*loading & 0.28 & 2 & 0.14 & 0.41 & 0.668 \\
\hline Nebulizer*loading & 1.58 & 4 & 0.39 & 1.16 & 0.352 \\
\hline Residual cup*loading & 3.61 & 12 & 0.30 & 0.89 & $0.57 \mathrm{I}$ \\
\hline Drug*nebulizer*residual cup & 9.45 & 12 & 0.79 & 2.32 & 0.038 \\
\hline Drug*nebulizer*loading & 1.79 & 4 & 0.45 & 1.32 & 0.293 \\
\hline Drug*residual cup*loading & 3.36 & 12 & 0.28 & 0.83 & 0.625 \\
\hline Nebulizer*residual cup*loading & 6.69 & 24 & 0.28 & 0.82 & 0.684 \\
\hline Error & 8.15 & 24 & 0.34 & & \\
\hline
\end{tabular}

Note: Statistically significant effects are shown in bold. *denotes interaction between effects.

Abbreviations: $d f$, degrees of freedom; MS, mean square; SS, sum of squares.

are already several products on the market. ${ }^{19,31}$ However, there are still some safety concerns with these drugs regarding their effect on the lung parenchyma and these need to be investigated further. ${ }^{32,33}$ In the case of inhaled insulin, it was observed that local absorption of the drug through the alveoli was different in the presence of a respiratory tract infection, so more frequent glucose level measurements were necessary. ${ }^{25}$ Several factors influence aerosol droplet production, the most important being jet nebulizer flow rate, ${ }^{34}$ tapping of the residual cup during nebulization, ${ }^{35,36}$ design of the residual cup, ${ }^{37}$ the chemical entity used, ${ }^{38,39}$ residual cup filling on initiation of nebulization, ${ }^{35}$ residual cup loading, ${ }^{40}$ viscosity, ${ }^{34}$ charge on the drug molecule, ${ }^{41}$ surface tension, and concentration of the drug solution. It has been observed that the salts present in the chemical structure of a drug are responsible for absorption of water from the environment and expansion of the molecule. Dry powder absorbs water from the environment, and according to the porosity of the

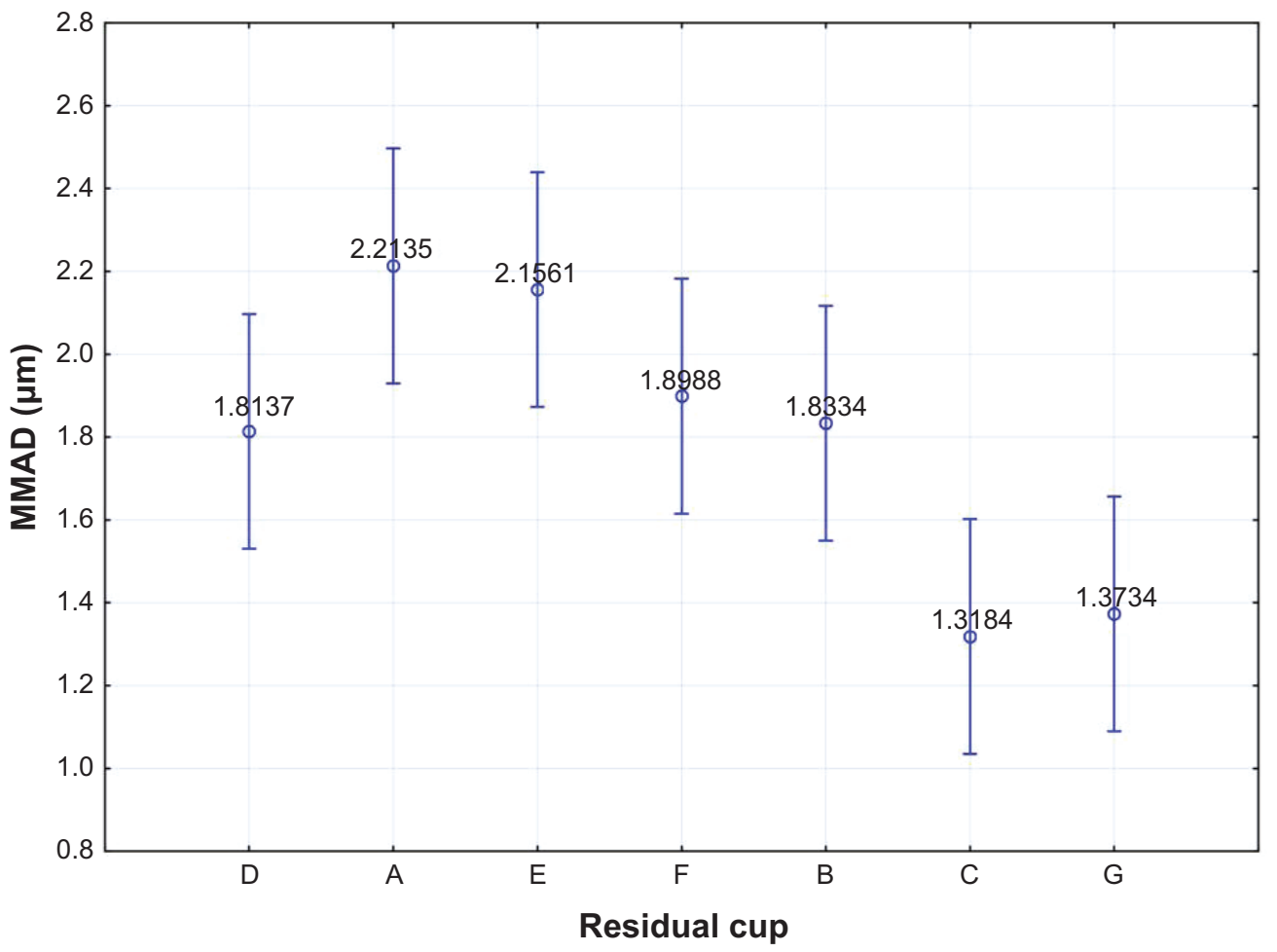

Figure 6 Mean mass median aerodynamic diameter (MMAD) values using various cup designs. Vertical lines denote the $95 \%$ confidence intervals extracted from the mean square error (analysis of variance). 


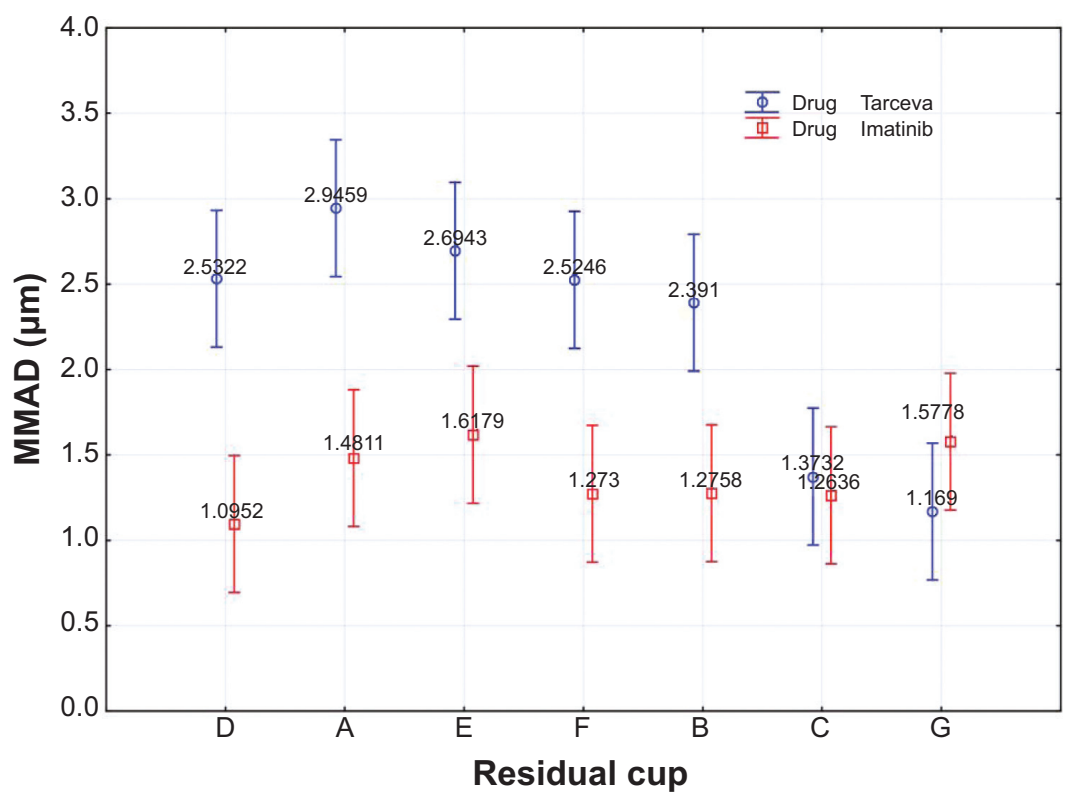

Figure 7 Mean mass median aerodynamic diameter (MMAD) values according to residual cups and drug inhalation. Vertical lines denote the $95 \%$ confidence intervals extracted from the mean square error (analysis of variance).

particles, expansion may be $50 \%-75 \%$ of the initial particle size. Further hydration may cause either expansion or contraction of the molecule (not applicable in the case of powder for concentration). The shape of the dry powder particle plays an important role in induction of cough. If one axis of a dry powder particle is larger, the mucosa of the respiratory system becomes irritated and cough is induced.

The major limitation of our study was that we did not evaluate the timing of aerosol production accurately in each experiment. This parameter is very important in designing any future aerosol product since the timing of administration is very important for the patient.

TKIs have been observed to block or reverse pulmonary fibrosis. ${ }^{42}$ Activation of the epidermal growth factor receptor (EGFR) pathway has been reported to activate proliferation of the microvasculature, so inhibition of EGFR has been proposed as an alternative treatment approach for $\mathrm{PH} .{ }^{43}$ A novel inhaled EGFR inhibitor has also been investigated for chronic obstructive pulmonary disease and could be used for $\mathrm{PH} .{ }^{44}$ Imatinib has been identified as a possible treatment

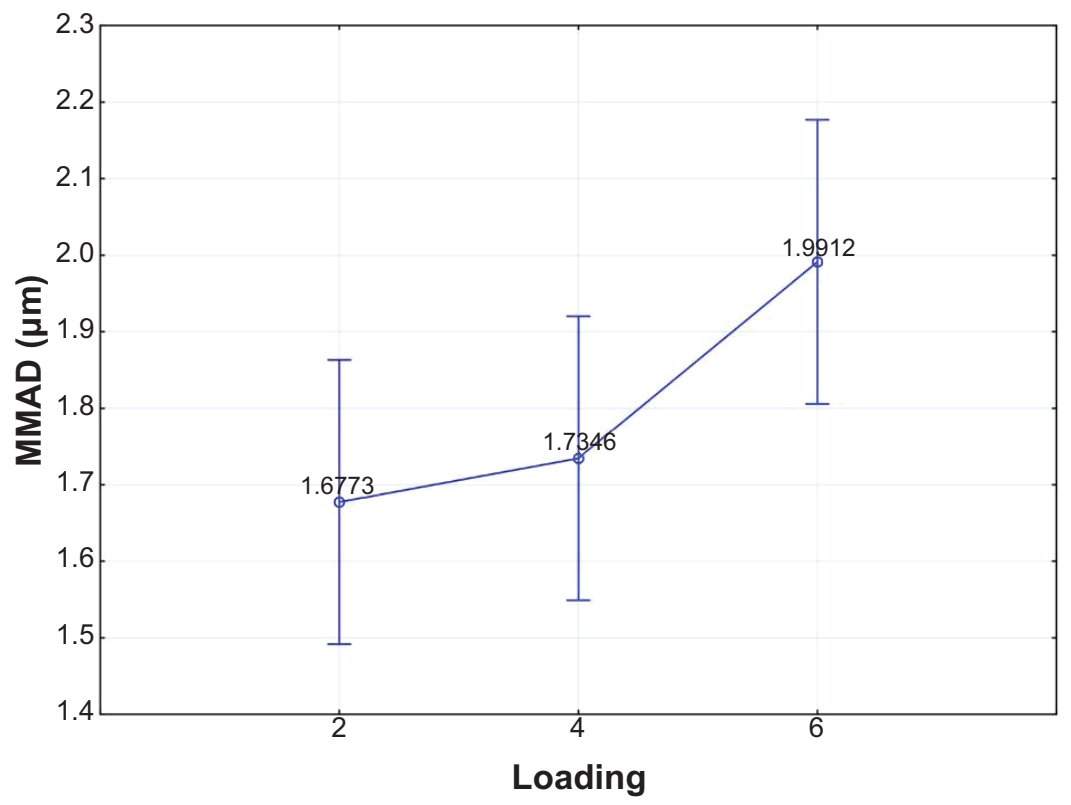

Figure 8 Mean mass median aerodynamic diameter (MMAD) changes with increasing loading levels. Vertical lines denote the $95 \%$ confidence intervals extracted from the mean square error (analysis of variance). 


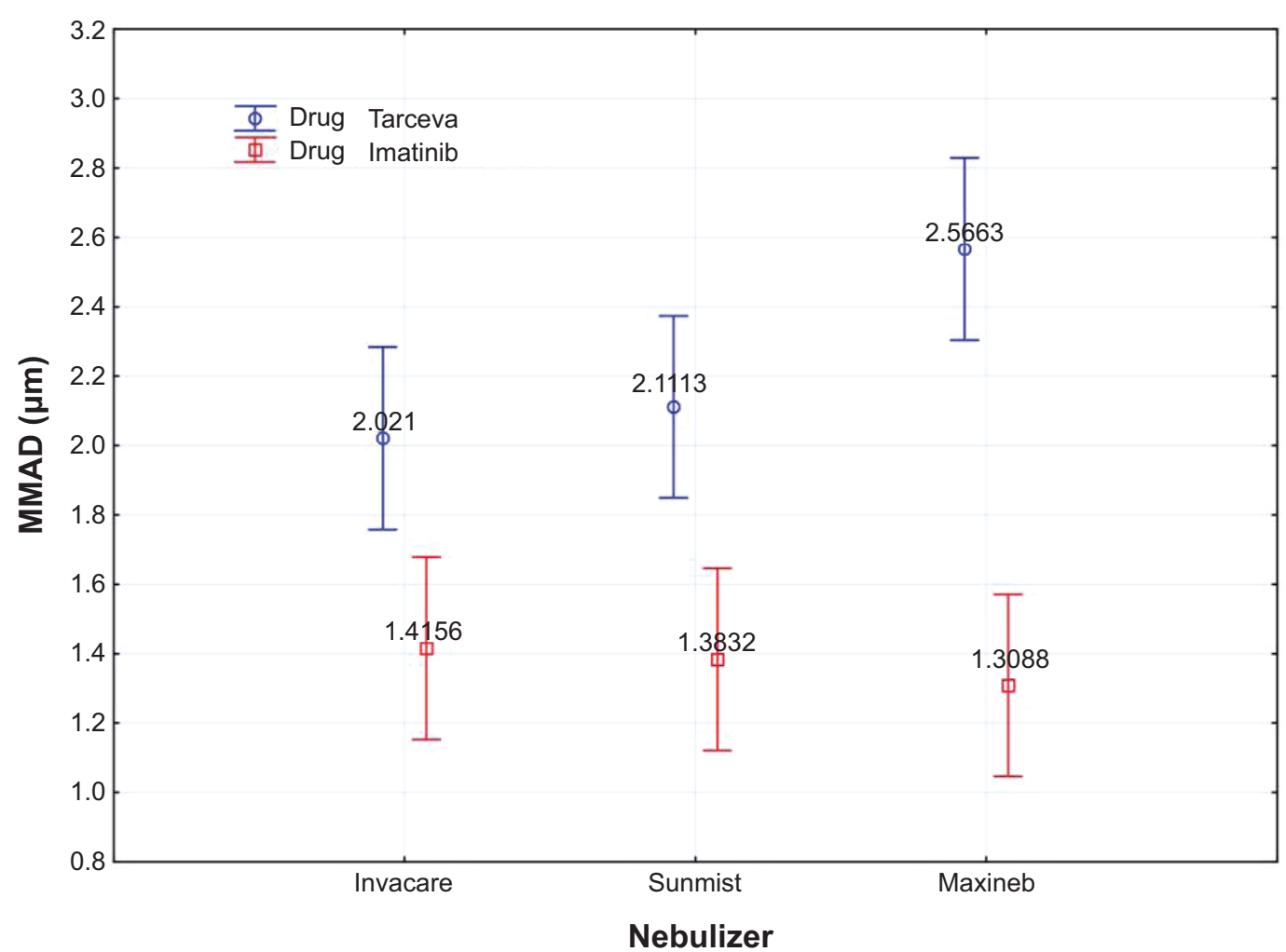

Figure 9 Mean mass median aerodynamic diameter (MMAD) values according to the combined performance of drugs and nebulizers. Vertical lines denote the $95 \%$ confidence intervals extracted from the mean square error (analysis of variance).

for hypereosinophilic syndrome presenting with cough. ${ }^{45}$ Another multikinase inhibitor that could be investigated as an aerosol is sorafenib, which has been found to be effective for vascular remodeling in arterial hypertension. ${ }^{46}$ In a study by Moreno-Vinasco et a ${ }^{47}$ it was noted again that sorafenib can be used to treat severe $\mathrm{PH}$ since it uses the mitogen-activated

Table 2 Analysis of variance of effect of four fixed factors and their interactions on mass median aerodynamic diameter

\begin{tabular}{|c|c|c|c|c|c|}
\hline Effect & ss & $d f$ & MS & $\boldsymbol{F}$ & $P$-value \\
\hline Drug & 8.58 & I & 8.58 & 49.01 & 0.020 \\
\hline Nebulizer & 3.12 & 2 & 1.56 & 8.93 & 0.101 \\
\hline Loading & 4.60 & I & 4.60 & 26.29 & 0.036 \\
\hline Mouthpiece & 3.79 & I & 3.79 & 21.65 & 0.043 \\
\hline Drug*nebulizer & 3.20 & 2 & 1.60 & 9.13 & 0.099 \\
\hline Drug*loading & 1.17 & 1 & 1.17 & 6.71 & 0.122 \\
\hline Nebulizer*loading & 1.79 & 2 & 0.90 & 5.12 & 0.163 \\
\hline Drug*mouthpiece & 0.50 & 1 & 0.50 & 2.85 & 0.233 \\
\hline Nebulizer*mouthpiece & 0.85 & 2 & 0.43 & 2.44 & 0.291 \\
\hline Loading*mouthpiece & 4.27 & I & 4.27 & 24.43 & 0.039 \\
\hline Drug*nebulizer*loading & 0.25 & 2 & 0.13 & 0.73 & 0.579 \\
\hline Drug*nebulizer*mouthpiece & 3.22 & 2 & 1.61 & 9.21 & 0.098 \\
\hline Drug*loading*mouthpiece & 0.30 & 1 & 0.30 & 1.70 & 0.322 \\
\hline Nebulizer*loading*mouthpiece & 0.49 & 2 & 0.25 & $\mathrm{I} .4 \mathrm{I}$ & 0.416 \\
\hline Error & 0.35 & 2 & 0.18 & & \\
\hline
\end{tabular}

Note: Statistically significant effects are shown in bold. *denotes interaction between effects.

Abbreviations: $d f$, degrees of freedom; MS, mean square; SS, sum of squares. protein kinase pathway. Imatinib has been used successfully to treat $\mathrm{PH}$ in a patient with chronic eosinophilic leukemia ${ }^{48}$ and also for patients with arterial hypertension. ${ }^{10,49,50}$ In the studies by Tang et $\mathrm{al}^{51}$ and Le Cras et $\mathrm{al}^{52}$ it was observed that vascular endothelial growth factor inhibitors can be used successfully to treat PH. Platelet-derived growth factor (PDGF)

Table 3 Mean values of mass median aerodynamic diameter and $95 \%$ confidence intervals for drugs, mouthpiece devices, loading levels, and nebulizers calculated from the mean square error (analysis of variance)

\begin{tabular}{lllll}
\hline & Mean & $-\mathbf{9 5} \%$ & $+\mathbf{9 5 \%}$ & $\mathbf{n}$ \\
\hline Drug & & & & \\
Erlotinib & 3.11 & 2.59 & 3.63 & 12 \\
$\quad$ Imatinib & 1.92 & 1.40 & 2.44 & 12 \\
$\begin{array}{l}\text { Mouthpiece } \\
\text { Facemask }\end{array}$ & 2.12 & 1.60 & 2.64 & 12 \\
Cone & 2.91 & 2.39 & 3.43 & 12 \\
Loading & & & & \\
2 & 2.08 & 1.56 & 2.60 & 12 \\
4 & 2.95 & 2.43 & 3.47 & 12 \\
Nebulizer & & & & \\
EASYneb & 2.88 & 2.25 & 3.52 & 8 \\
Gima & 2.64 & 2.00 & 3.27 & 8 \\
Omron & 2.02 & 1.39 & 2.66 & 8 \\
\hline
\end{tabular}




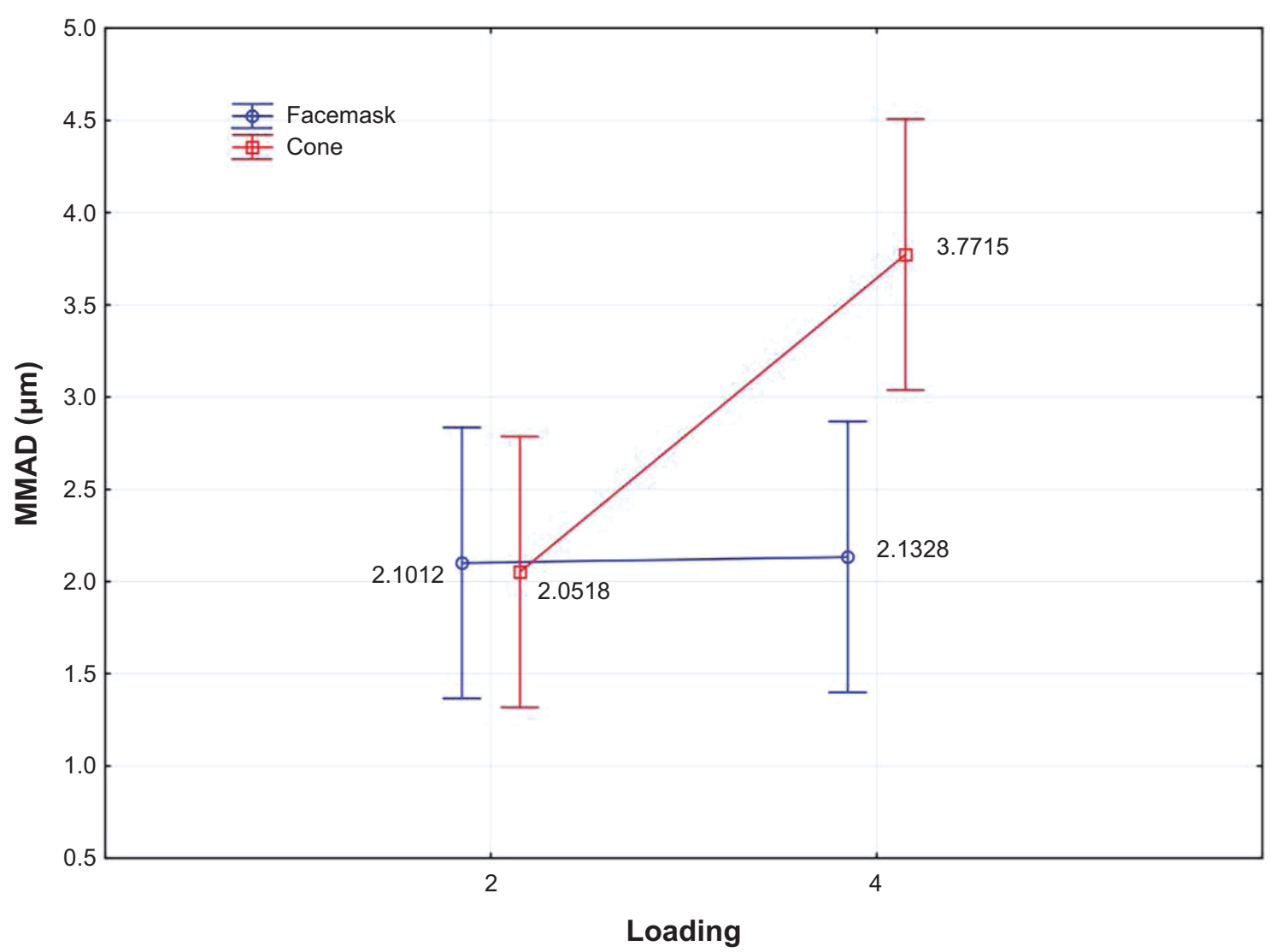

Figure 10 Mean mass median aerodynamic diameter (MMAD) values according to loading levels and mouthpiece devices. Vertical lines denote the $95 \%$ confidence intervals extracted from the mean square error (analysis of variance).

inhibitors have been also proposed as a treatment for $\mathrm{PH}^{53}$ In a study by Nakamura et $\mathrm{al}^{54}$ it was observed that imatinib inhibits the PDGF pathway. Kosanovic and Schermuly ${ }^{55}$ further proposed that inhibiting the PDGF pathway is more effective in the treatment of $\mathrm{PH}$ because it also blocks fibrinogenesis. The rho-kinase inhibitors have also been suggested as a treatment for $\mathrm{PH}^{56,57}$ Dasatinib was reported to induce $\mathrm{PH}$ when used in a patient with chronic myeloid leukemia. ${ }^{58}$ In a study by Hennigs et $\mathrm{al}^{59}$ dasatinib was again identified as a novel cause of severe precapillary PH. However, safety concerns have been raised when using TKIs to treat $\mathrm{PH}$, with a special focus on cardiac repolarization. ${ }^{60,61}$ Currently, another Syk kinase inhibitor is under development for inhalation by Pfizer and is being investigated in a Phase I study. ${ }^{62}$ Rapamycin was found to reverse proliferation of pulmonary artery smooth muscle cells, indicating that inhaled rapamycin should be investigated for this disease. ${ }^{63}$ Finally, Src TKIs could be another novel treatment for $\mathrm{PH}{ }^{64}$

Our current research indicates that TKIs already on the market can be modified to be produced as aerosols that could be used as an aerosol treatments for PH. Specifically, imatinib, which we already know causes severe dose-dependent side effects when administered systemically, could be administered as an aerosol. A future clinical trial is needed to determine the effectiveness of aerosolized TKIs for PH. In our current study, the major findings were that the performance of imatinib was superior to that of erlotinib with regard to small droplet size formation using both inhaled technologies $(1.37 \mu \mathrm{m}<2.23 \mu \mathrm{m}$ and $1.92 \mu \mathrm{m}<3.11 \mu \mathrm{m}$, jet and ultrasound, respectively) and when the drug is considered alone with jet devices it produces even smaller droplets. $(1.37 \mu \mathrm{m}$ $<1.92 \mu \mathrm{m})$. Cup designs $\mathrm{C}$ and $\mathrm{G}$ contributed best to small droplet size creation supporting uniquely and equally well the activity of both drugs. The disadvantage of the large droplets formed by erlotinib was canceled out when combined with residual cup $\mathrm{C}(1.37 \mu \mathrm{m}$ instead of $2.23 \mu \mathrm{m})$. At the $2 \mathrm{~mL}$ dose, the facemask and cone mouthpieces perform best and evenly $(2.08 \mu \mathrm{m}$ and $2.12 \mu \mathrm{m}$, respectively). Gefitinib was impossible to manipulate in its current tablet formulation.

\section{Disclosure}

The authors report no conflicts of interest in this work. 


\section{References}

1. Badesch DB, Champion HC, Sanchez MA, et al. Diagnosis and assessment of pulmonary arterial hypertension. J Am Coll Cardiol. 2009; 54(1 Suppl):S55-S66.

2. McLaughlin VV, Archer SL, Badesch DB, et al. ACCF/AHA 2009 expert consensus document on pulmonary hypertension: a report of the American College of Cardiology Foundation Task Force on Expert Consensus Documents and the American Heart Association: developed in collaboration with the American College of Chest Physicians, American Thoracic Society, Inc., and the Pulmonary Hypertension Association. Circulation. 2009;119(16):2250-2294.

3. Barst RJ, McGoon M, Torbicki A, et al. Diagnosis and differential assessment of pulmonary arterial hypertension. $J$ Am Coll Cardiol. 2004;43(12 Suppl S):40S-47S.

4. Sitbon O, Humbert M, Jais X, et al. Long-term response to calcium channel blockers in idiopathic pulmonary arterial hypertension. Circulation. 2005;111(23):3105-3111.

5. Torres F. Systematic review of randomised, double-blind clinical trials of oral agents conducted in patients with pulmonary arterial hypertension. Int J Clin Pract. 2007;61(10):1756-1765.

6. Godinas L, Guignabert C, Seferian A, et al. Tyrosine kinase inhibitors in pulmonary arterial hypertension: a double-edge sword? Semin Respir Crit Care Med. 2013;34(5):714-724.

7. Nakamura K, Akagi S, Sarashina T, Ogawa A, Matsubara H, Ito H. [Treatment with imatinib for refractory PAH]. Nihon Yakurigaku Zasshi. 2014;143(4):173-177. Japanese.

8. Toba M, Alzoubi A, O'Neill K, et al. A novel vascular homing peptide strategy to selectively enhance pulmonary drug efficacy in pulmonary arterial hypertension. Am J Pathol. 2014;184(2):369-375.

9. Arita S, Arita N, Hikasa Y. Therapeutic effect of low-dose imatinib on pulmonary arterial hypertension in dogs. Can Vet J. 2013;54(3): 255-261.

10. Pankey EA, Thammasiboon S, Lasker GF, Baber S, Lasky JA, Kadowitz PJ. Imatinib attenuates monocrotaline pulmonary hypertension and has potent vasodilator activity in pulmonary and systemic vascular beds in the rat. Am J Physiol Heart Circ Physiol. 2013;305(9): H1288-H1296.

11. Mucke $H$. The role of imatinib in the treatment of pulmonary hypertension. Drugs Today (Barc). 2013;49(3):203-211.

12. Domvri K, Zarogoulidis P, Darwiche K, et al. Molecular targeted drugs and biomarkers in NSCLC, the evolving role of individualized therapy. J Cancer. 2013;4(9):736-754.

13. Zarogoulidis K, Zarogoulidis P, Darwiche K, et al. Treatment of non-small cell lung cancer (NSCLC). J Thorac Dis. 2013;5 Suppl 4:S389-S396.

14. Souza R, Sitbon O, Parent F, Simonneau G, Humbert M. Long term imatinib treatment in pulmonary arterial hypertension. Thorax. 2006; 61(8):736.

15. Zarogoulidis $\mathrm{P}$, Darwiche $\mathrm{K}$, Huang $\mathrm{H}$, et al. Time recall; future concept of chronomodulating chemotherapy for cancer. Curr Pharm Biotechnol. 2013;14(6):632-642.

16. Zaric B, Stojsic V, Tepavac A, et al. Adjuvant chemotherapy and radiotherapy in the treatment of non-small cell lung cancer (NSCLC). J Thorac Dis. 2013;5 Suppl 4:S371-S377.

17. Boukovinas I, Tsakiridis K, Zarogoulidis $\mathrm{P}$, et al. Neo-adjuvant chemotherapy in early stage non-small cell lung cancer. $J$ Thorac Dis. 2013;5 Suppl 4:S446-S448.

18. Zarogoulidis P, Petridis D, Ritzoulis C, et al. Internal mouthpiece designs as a future perspective for enhanced aerosol deposition. Comparative results for aerosol chemotherapy and aerosol antibiotics. Int J Pharm. 2013;456(2):325-331.

19. Zarogoulidis P, Kioumis I, Ritzoulis C, et al. New insights in the production of aerosol antibiotics. Evaluation of the optimal aerosol production system for ampicillin-sulbactam, meropenem, ceftazidime, cefepime and piperacillin-tazobactam. Int J Pharm. 2013;455(1-2):182-188.

20. Ulivi P, Zoli W, Capelli L, Chiadini E, Calistri D, Amadori D. Target therapy in NSCLC patients: relevant clinical agents and tumour molecular characterisation. Mol Clin Oncol. 2013;1(4):575-581.
21. Madhusudan S, Ganesan TS. Tyrosine kinase inhibitors and cancer therapy. Recent Results Cancer Res. 2007;172:25-44.

22. Madhusudan S, Ganesan TS. Tyrosine kinase inhibitors in cancer therapy. Clin Biochem. 2004;37(7):618-635.

23. Abe K, Toba M, Alzoubi A, et al. Tyrosine kinase inhibitors are potent acute pulmonary vasodilators in rats. Am J Respir Cell Mol Biol. 2011; 45(4):804-808.

24. Zarogoulidis P, Darwiche K, Yarmus L, et al. Defense mechanisms of the respiratory system and aerosol production systems. Med Chem. 2014;10(2):123-136.

25. Zarogoulidis P, Papanas N, Kouliatsis G, Spyratos D, Zarogoulidis K, Maltezos E. Inhaled insulin: too soon to be forgotten? J Aerosol Med Pulm Drug Deliv. 2011;24(5):213-223.

26. Zarogoulidis P, Eleftheriadou E, Sapardanis I, et al. Feasibility and effectiveness of inhaled carboplatin in NSCLC patients. Invest New Drugs. 2012;30(4):1628-1640.

27. Zarogoulidis P, Petridis D, Ritzoulis C, et al. Establishing the optimal nebulization system for paclitaxel, docetaxel, cisplatin, carboplatin and gemcitabine: back to drawing the residual cup. Int J Pharm. 2013; 453(2):480-487.

28. Zarogoulidis P, Darwiche K, Krauss L, et al. Inhaled cisplatin deposition and distribution in lymph nodes in stage II lung cancer patients. Future Oncol. 2013;9(9):1307-1313.

29. Zarogoulidis P, Chatzaki E, Porpodis K, et al. Inhaled chemotherapy in lung cancer: future concept of nanomedicine. Int $J$ Nanomedicine. 2012;7:1551-1572.

30. Zarogoulidis P, Petridis D, Ritzoulis C, et al. Further experimentation of inhaled; Lantus, Actrapid and Humulin with todays' production systems. Int J Pharm. 2013;458(1):39-47.

31. Zarogoulidis P, Kioumis I, Porpodis K, et al. Clinical experimentation with aerosol antibiotics: current and future methods of administration. Drug Des Devel Ther. 2013;7:1115-1134.

32. Zarogoulidis P, Giraleli C, Karamanos NK. Inhaled chemotherapy in lung cancer: safety concerns of nanocomplexes delivered. Ther Deliv. 2012;3(9):1021-1023.

33. Darwiche K, Zarogoulidis P, Karamanos NK, et al. Efficacy versus safety concerns for aerosol chemotherapy in non-small-cell lung cancer: a future dilemma for micro-oncology. Future Oncol. 2013;9(4): 505-525.

34. Clay MM, Pavia D, Newman SP, Clarke SW. Factors influencing the size distribution of aerosols from jet nebulisers. Thorax. 1983;38(10): 755-759.

35. Kendrick AH, Smith EC, Wilson RS. Selecting and using nebuliser equipment. Thorax. 1997;52 Suppl 2:S92-S101.

36. Hoffmann N, Duft D, Kiselev A, Leisner T. Contact freezing efficiency of mineral dust aerosols studied in an electrodynamic balance: quantitative size and temperature dependence for illite particles. Faraday Discuss. 2013;165:383-390.

37. Newman SP, Pellow PG, Clay MM, Clarke SW. Evaluation of jet nebulisers for use with gentamicin solution. Thorax. 1985;40(9): 671-676.

38. Davis JM, Davies IA. Some physico-chemical characteristics of the antigens of Ehrlich ascites-tumour cells. Biochem Soc Trans. 1980;8(4): 436-437.

39. Buttini F, Miozzi M, Balducci AG, et al. Differences in physical chemistry and dissolution rate of solid particle aerosols from solution pressurised inhalers. Int J Pharm. 2014;465(1-2):42-51.

40. Kendrick AH, Smith EC, Denyer J. Nebulizers - fill volume, residual volume and matching of nebulizer to compressor. Respir Med. 1995; 89(3): 157-159.

41. Kwok PC, Trietsch SJ, Kumon M, Chan HK. Electrostatic charge characteristics of jet nebulized aerosols. J Aerosol Med Pulm Drug Deliv. 2010;23(3):149-159.

42. Hardie WD, Davidson C, Ikegami M, et al. EGF receptor tyrosine kinase inhibitors diminish transforming growth factor-alphainduced pulmonary fibrosis. Am J Physiol Lung Cell Mol Physiol. 2008;294(6):L1217-L1225. 
43. Toby IT, Chicoine LG, Cui H, Chen B, Nelin LD. Hypoxia-induced proliferation of human pulmonary microvascular endothelial cells depends on epidermal growth factor receptor tyrosine kinase activation. Am J Physiol Lung Cell Mol Physiol. 2010;298(4):L600-L606.

44. Woodruff PG, Wolff M, Hohlfeld JM, et al. Safety and efficacy of an inhaled epidermal growth factor receptor inhibitor (BIBW 2948 BS) in chronic obstructive pulmonary disease. Am J Respir Crit Care Med. 2010;181(5):438-445.

45. Kobayashi M, Kubota T, Uemura Y, Taguchi H. A case of hypereosinophilic syndrome presenting with chronic cough successfully treated with imatinib. Respirology. 2009;14(2):302-304.

46. Klein M, Schermuly RT, Ellinghaus P, et al. Combined tyrosine and serine/threonine kinase inhibition by sorafenib prevents progression of experimental pulmonary hypertension and myocardial remodeling. Circulation. 2008;118(20):2081-2090.

47. Moreno-Vinasco L, Gomberg-Maitland M, Maitland ML, et al. Genomic assessment of a multikinase inhibitor, sorafenib, in a rodent model of pulmonary hypertension. Physiol Genomics. 2008;33(2):278-291.

48. Krauth MT, Binder T, Ohler L, Jager U, Valent P. Improvement of cardiac function, mitral regurgitation and pulmonary hypertension in a patient with chronic eosinophilic leukemia (CEL) after low dose imatinib therapy. Leuk Res. 2008;32(11):1779-1783.

49. Ghofrani HA, Morrell NW, Hoeper MM, et al. Imatinib in pulmonary arterial hypertension patients with inadequate response to established therapy. Am J Respir Crit Care Med. 2010;182(9):1171-1177.

50. Ciuclan L, Hussey MJ, Burton V, et al. Imatinib attenuates hypoxiainduced pulmonary arterial hypertension pathology via reduction in 5-hydroxytryptamine through inhibition of tryptophan hydroxylase 1 expression. Am J Respir Crit Care Med. 2013;187(1):78-89.

51. Tang JR, Markham NE, Lin YJ, et al. Inhaled nitric oxide attenuates pulmonary hypertension and improves lung growth in infant rats after neonatal treatment with a VEGF receptor inhibitor. Am J Physiol Lung Cell Mol Physiol. 2004;287(2):L344-L351.

52. Le Cras TD, Markham NE, Tuder RM, Voelkel NF, Abman SH. Treatment of newborn rats with a VEGF receptor inhibitor causes pulmonary hypertension and abnormal lung structure. Am J Physiol Lung Cell Mol Physiol. 2002;283(3):L555-L562.
53. Grimminger F, Schermuly RT. PDGF receptor and its antagonists: role in treatment of PAH. Adv Exp Med Biol. 2010;661:435-446.

54. Nakamura K, Akagi S, Ogawa A, et al. Pro-apoptotic effects of imatinib on PDGF-stimulated pulmonary artery smooth muscle cells from patients with idiopathic pulmonary arterial hypertension. Int J Cardiol. 2012;159(2):100-106.

55. Kosanovic D, Schermuly R. Are tyrosine kinase inhibitors the better serotonin inhibitors? Am J Respir Crit Care Med. 2013;187(1):4-5.

56. Ziino AJ, Ivanovska J, Belcastro R, et al. Effects of rho-kinase inhibition on pulmonary hypertension, lung growth, and structure in neonatal rats chronically exposed to hypoxia. Pediatr Res. 2010;67(2): $177-182$.

57. Oka M, Homma N, Taraseviciene-Stewart L, et al. Rho kinase-mediated vasoconstriction is important in severe occlusive pulmonary arterial hypertension in rats. Circ Res. 2007;100(6):923-929.

58. Ryczek R, Gora-Tybor J, Betkier-Lipinska K, Cwetsch A. [Reversible pulmonary hypertension as a consequence of dasatinib treatment in a patient with chronic myeloid leukemia and scleroderma]. Pol Merkur Lekarski. 2013;34(204):342-344. Polish.

59. Hennigs JK, Keller G, Baumann HJ, et al. Multi tyrosine kinase inhibitor dasatinib as novel cause of severe pre-capillary pulmonary hypertension? BMC Pulm Med. 2011;11:30.

60. Shah RR, Morganroth J, Shah DR. Cardiovascular safety of tyrosine kinase inhibitors: with a special focus on cardiac repolarisation (QT interval). Drug Saf. 2013;36(5):295-316.

61. Dasanu CA, Padmanabhan P, Clark BA 3rd, Do C. Cardiovascular toxicity associated with small molecule tyrosine kinase inhibitors currently in clinical use. Expert Opin Drug Saf. 2012;11(3):445-457.

62. Norman P. A novel Syk kinase inhibitor suitable for inhalation: R-343(?)WO-2009031011. Expert Opin Ther Pat. 2009;19(10):1469-1472.

63. Houssaini A, Abid S, Mouraret N, et al. Rapamycin reverses pulmonary artery smooth muscle cell proliferation in pulmonary hypertension. Am J Respir Cell Mol Biol. 2013;48(5):568-577.

64. Pullamsetti SS, Berghausen EM, Dabral S, et al. Role of Src tyrosine kinases in experimental pulmonary hypertension. Arterioscler Thromb Vasc Biol. 2012;32(6):1354-1365.

\section{Publish your work in this journal}

Drug Design, Development and Therapy is an international, peerreviewed open-access journal that spans the spectrum of drug design and development through to clinical applications. Clinical outcomes, patient safety, and programs for the development and effective, safe, and sustained use of medicines are a feature of the journal, which

\section{Dovepress}

has also been accepted for indexing on PubMed Central. The manuscript management system is completely online and includes a very quick and fair peer-review system, which is all easy to use. Visit http://www.dovepress.com/testimonials.php to read real quotes from published authors. 